\title{
Enzymatic Modified Starch as Binder Component of Coating Color for Coated Paper
}

\author{
Nina Elyani Jenni R. Teddy K. \\ Center for Pulp and Paper
}

\begin{abstract}
Coated paper is a type of printing paper; coated one or both sides, with or without supercalendar finishing. The uniformity of coating color distribution on the paper surface is one of important factor affecting the quality of coated paper produced. Viscosity of coating color is significantly influenced the uniformity of its distribution on the paper surface. The lower the viscosity, the higher the uniformity of coating color distribution. The use of native starch as viscosity control additive in coating color has limitations. It causes high viscosity in coating color. The use of enzymatic modified starch as additive of coating color have been investigated.These study were conducted in several steps. Step I was base papermaking using $80 \%$ LBKP and $20 \%$ NBKP after refining separately up to $315 \mathrm{ml} \mathrm{CSF}$. Then, $15 \% \mathrm{CaCO} 3,0,6 \% \mathrm{AKD}, 0,5 \%$ poliacrylamide, and 1,5\% cationic starch base on dry-weight of fibers was added to the fiber mixture. Step II was modification of starch enzymaticaly at $70-75^{\circ} \mathrm{C}$, pH 6,5 - 7,0, 0,05\% amylase, for 15 minutes. Step III was base-paper coating process using native starch (variation I), enzymatic modified starch (variation II), and commercial starch (variation III) of $8 \%$ each. The handsheets were tested for brightness, roughtness, picking strength, Cobb size, and $\mathrm{pH}$. The results showed that the viscosity of native starch, enzymatic modified starch and commercial starch were $8000 \mathrm{cPs}, 26 \mathrm{cPs}$ and $114 \mathrm{cPs}$ respectively. The use of enzymatic modified starch gave the best paper properties. The similar results were showed for the experiments conducted in the paper industry's laboratory using the mixture of clay and $\mathrm{CaCO}_{3}$ at 40:60 ratio, and the same enzymatic modified starch, commercial starch, and native starch.
\end{abstract}

Keywords : starch, coated printing paper, amylase, viscosity.

DOI: $10.7176 / \mathrm{CMR} / 11-9-04$

Publication date: November $30^{\text {th }} 2019$

\section{Introduction}

Coated printing paper is a type of printing paper made from chemical pulp, or it mixture with maximum of $15 \%$ mechanical pulp. It has a good printing properties such as smoothness, opacity and gloss, coated one or both sides and with or without supercalendar finishing process. This paper is commonly used for printing calendars, magazines, book covers and others. Coated printing papermaking process is done through base papermaking process followed by a coating material preparation, manufacturing of coating color, and coating process it self.

The quality of coated paper is strongly influenced by the properties of base paper. The important properties of base paper are sheet uniformity, porosity, physical strength, moisture content, brightness, opacity and smoothness (YV Sood et al, 2010). In addition, it should be noted the coating color components, such as pigment, binder and additives. Pigment is the main component in coating color. It is commonly used between $70-90 \%$ of the total coating color mixture. The common types of pigment used are clay, calcium carbonate, titanium dioxide and satin white (Lehtinen and Mueller, 2005). While the common binders used are starch, casein, styrenebutadiene rubber, acrylic, polyvinyl alcohol (PVA) and polyvinyl acetate (PVAc) which are partly still imported. The binder has a considerable influence on the properties of coating color and final coated printing paper produced. In order to generate a coating color mixture with high colloidal stability, the binder used should be compatible to the pigment, so that the nature of the coating color will not change during the process.

Binder is a carrier of pigments. It binds the pigment particles and as well as pigment particles with base paper, forms the required flow properties of coating color and water retention of the coating color to control the absorption of printing ink onto paper during printing process (Lehtinen, 2000 ).

In the paper industry, the starch used is generally chemically modified to produce starch solution with still relatively high viscosity, so that the uneven distribution of coating color is generated which resulting less inequality adhesion between the pigment to the paper. On enzymatic modified starch manufacturing research, the viscosity of starch solution expected is as low as possible. So that, it can be dispersed and distributed uniformly onto the base paper and produce a coated paper with good quality.

The modification of native starch using alpha amylase enzyme have been done in CPP's laboratory and the laboratory of one paper industry. The results were compared to the native and commecial starches. It was expected that the modified starch resulted improved the quality of coated paper produced. The scope of study were consisted of base papermaking, enzymatic modification of starch and the laboratory trial of coating process, both at the CPP and one of paper industry. 


\section{Experimental}

The experiments carried out in CPP's laboratory were base papermaking, enzymatic modification of starch, coating process of base paper, and testing of coated paper resulted.

The materials used in this study were leaf bleached kraft pulp (LBKP), needle bleached kraft pulp (NBKP), alkyl ketene dymer $(\mathrm{AKD})$, calcium carbonate $\left(\mathrm{CaCO}_{3}\right)$, native starch, cationic starch, polyacrylamide, clay, latex, enzymatic modified starch, commercial starch and PVA (Polyvinyl alcohol), dispersant, lubricant, defomer, insolubilizer and biocide.

The equipements used including analytical balance, drying oven, dish, desicator, measuring glass, glassware, Niagara Beater, freeness tester, $\mathrm{pH}$-meter, thermometer, hot plate, agitator, and Brookfield viscometer for viscosity determination, proofer coater, drying plate, crus tang, and paper testing equipments such as Photovolt, Bendtsen and IGT printability tester.

The laboratory experiments were carried out in a some stages as described below.

\section{Base papermaking}

Long fiber and short fiber were refined separately using Niagara Beater upto $315 \mathrm{ml} \mathrm{CSF}$ of freeness and then blended with the composition of $20 \%$ long fiber and $80 \%$ short fiber. $15 \%$ of calcium carbonate, $0.6 \%$ of alkyl ketene dymer (AKD), $1.5 \%$ of cationic starch and $0.5 \%$ of polyacrylamide were added into the fiber furnish. The addition of all additives were based on dry basis of fiber. The handsheets of $60 \mathrm{gsm}$ grammage were made, and then pressed and dried. The handsheets resulted were used as a coating base paper. Figure 1 describes the flow diagram of coating base papermaking process.

2. Starch solution preparation

a. Native starch

25 gram of native starch was dispersed in $100 \mathrm{~mL}$ of water. Starch was added gradually into the water while agitated continuesly. After that, the dispersion was heated for 30 minutes at the temperature of $70-80^{\circ} \mathrm{C}$ and then cooled down upto room temperature and tested for viscosity.

b. Enzymatic modified starch

The same starch solution was used as a raw material of enzymatic modification. 25 gram of native starch was dispersed in $100 \mathrm{~mL}$ of water. Starch was added gradually into the water while agitated continuesly. $0.05 \%$ of enzyme was added intothe starch solution and then heated upto $70-75^{\circ} \mathrm{C}$ of temperature. After starch solution was cooked $\left( \pm 75^{\circ} \mathrm{C}\right)$, the solution was keep for 15 minutes at the constant temperature of $75{ }^{\circ} \mathrm{C}$. After that was heated upto $90{ }^{\circ} \mathrm{C}$ of temperatur in 5 minutes to stop the reaction of enzyme and then cooled down upto room temperature and tested for viscosity.

c. Commercial starch

The same procedure of native stach solution preparation was applied for commercial starch.

3. Coating color preparation and coating process

Firstly, the dispersant was dissolved in water and mixed thoroughly. The dry pegments of $\mathrm{CaCO}_{3}$ and clay were added gradually, and then latex, PVA and starch (see Table 1). The total solid of coating color mixture was $50 \%$. The mixture of coating color was then agitated for 30 minutes and ready to use for coating process. One side coated paper was made by pouring $10 \mathrm{~mL}$ of coating color onto the base paper and then distributed evenly using the poofer coater. The coated paper resulted was still wet, so that it was dried at room temperature for 24 hours.

4. Testing of coated papers

Coated papers resulted from the experiment were conditioned for 24 hours in a room with the temperature and relative humidity of $23 \pm 1{ }^{\circ} \mathrm{C}$ and $50 \pm 2 \%$ respectively and then tested for brightness, roughness (Bendtsen), IGT oil penetration and picking strength, Cobb size, and $\mathrm{pH}$.

\section{Results and discussion}

1. Viscosity of starch solution

The test results of starch viscosity are $8000 \mathrm{cPs}$ for native starch, $26 \mathrm{cPs}$ for enzymatic modified starch, and $114 \mathrm{cPs}$ for commercial imported starch. Low viscosity of enzymatic modified starch was due to hydrolysis of starch by amylase producing glucose and maltose molecule which is soluble in water. Decreasing of starch viscosity is needed to improve dispersion of coating color and distribution of coating color on the surface of coating-base paper. This strengthen the bonding of pigment to the surface of coating-base paper (Werner, 2006).

2. Properties of coated paper

Coated paper resulted from coating trial in CPP Laboratory as well as Industrial Laboratory were tested for brightness, roughness (Bendtsen), oil penetration and picking strength (IGT), Cobb size (Cobb 60$)$, and $\mathrm{pH}$. The test results can be seen in Table 2

Brightness

Brightness is defined as ratio of blue light intensity at $457 \mathrm{~nm}$ of wave length, reflected by paper or 
paperboard surface at diffuse illumination and $0^{\circ}$ observation, stated in $\%$. Pigments are significantly influenced the brightness of paper as well as color pigments to the color of papers. Some filler used generates the difference of brightness between both paper surfaces due to the difference of accumulation of filler on each paper surface. The test results showed that the brightness of coated paper were $76,79,81$, and $79 \%$ for variation 1, 2, and 3 respectively. The use of enzymatic modified starch in coating color increases the binding ability of the pigments to the paper surface resulting relatively high brightness of coated paper compared to the others. The influence of starch variation to the brightness of coated paper can be seen on Figure 1.

Roughness

Roughness is amount of milliliter air per time unit which can be passing through the gap of surface paper or board with metal ring plate laid on the surface, measured in standard condition. The roughness of paper surface is important for ink absorption and printability. Paper surface roughness is influenced by fiber type and structure, formation, the level of sheet consolidation by pressing and calendaring, and other components such as filler, coating, and surface sizing (Smook, 2002). Table 2 shows the roughness of coated papers resulted of $800,700,600$, and $700 \mathrm{~mL} / \mathrm{mnt}$ for blank, native starch, enzymatic modified starch, and commercial starch respectively. The influence of starch variation on the roughness of coated paper can be seen on Figure 2 bellow.

Oil penetration

Oil penetration is defined as the property of paper for absorption of standard liquid, calculated inversely as the length of printing ink spot on paper sample, stated as $1000 / \mathrm{mm}$, measured by IGT Printability Tester at standard condition. One of printability requirement of paper, both plain and coated papers, is ink hold-out which means the affinity of paper surface to the ink and the absorption of ink into paper surface. For coated paper, this is effected by the binder used in coating color. Some pigments such as precipitated calcium carbonate and clay which is slightly heated, increase the ink absorptivity of the paper (Werner, 2006).

The test results in Figure 3 showed that the oil penetration were 40, 25, 21, and 26 1000/mm for blank, native starch, enzymatic modified starch, and commercial starch respectively. The usage of enzymatic modified starch resulted in the highest value of oil penetration compared to native and commercial starch. This is due to the low viscosity of modified starch, improves the dispersion of coating color and distribution of coating color on the surface of coating-base paper.

Picking strength

Picking strength of paper surface is influenced significantly by the amount of binder usage in coating color and the distribution of coating color on the paper surface. The test results of picking strength were 164, 335, 432, and 357 P.m/s for blank, native starch, enzymatic modified starch, and commercial starch respectively (Figure 4).

The usage of enzymatic modified starch as an additive of binder in coating color produced the highest picking strength value compared to native and commercial commercial starch. This is also due to the low viscosity of modified starch, improves the dispersion of coating color and distribution of coating color on the surface of coating-base paper. The characteristic of higher bonding ability of enzymatic modified starch compared to native one is also identified in some references i.e. Holik, and Y.V. Sood et al., 2010.

Water absorptivity or Cobb size

Water absorptivity or Cobb size $\left(\mathrm{Cobb}_{60}\right)$ is the amount of water in grams which can be absorbed by $1 \mathrm{~m}^{2}$ of paper or paperboard, measured at standard condition. The lower absorption value means the higher of water penetration resistance of the sheets. Water absorptivity is one of important properties for printing and writing papers. The test results showed that the water absorptivity value are 113,78 , and $90 \mathrm{~g} / \mathrm{m}^{2}$ for native starch, enzymatic modified starch and commercial starch respectively (Figure 5).

$p H$

$\mathrm{pH}$ of paper is defined as negative logarithmic of hydrogen ion concentration in water extract of paper, measured at standard condition. $\mathrm{pH}$ value is responsible for paper permanence especially for archive paper. The test results showed the $\mathrm{pH}$ value were $6.8,6.9,7.0$, and 6.9 for blank, native starch, enzymatic modified starch and commercial starch respectively (Figure 6).

3. The test results of coated paper in industrial laboratory trial

The test results can be seen on the following Table 3 .

Brightness

The brightness of coated papers resulted from industrial laboratory trial were $80.00,81.00$, and $80.81 \%$ for native, modified, and commercial starch respectively. Enzymatic modified starch gives the highest value of brightness. This is due to the increasing of pigment content in paper surface due to the higher bonding resulted by this starch as well as the uniformity of dispersion and distribution of coating pigment on the surface of paper. 


\section{Picking Strength}

Picking strength values for native, modified, and commercial starch were 404.2, 493.5, and 451.2 P.m/s. Enzymatic modified starch gave the best value of picking strength compared to native and commercial starch due to the uniformity of dispersion and distribution of starch as coating binder on the surface of paper. This only can happen because the enzymatic modified starch has a lower viscosity compared to native and commercial starch.

Water Absorptivity or Cobb size

Water absorptivity or Cobb size $\left(\mathrm{Cobb}_{60}\right)$ of native, enzymatic modified and commercial starch were 22.3, 20.8 , and $21.7 \mathrm{~g} / \mathrm{m}^{2}$. The lower the absorptivity value means the the higher of water penetration resistance of the sheets. Water absorptivity is an important factor for printing and writing printing paper. The results showed that enzymatic modified starch give the best value for water absorptivity compared to native and commercial starch.

\section{CONCLUSIONS}

1. The viscosity of enzymatic modified starch was $26 \mathrm{cP}$, significantly lower than native starch $(8000 \mathrm{cP})$ and imported commercial starch $(114 \mathrm{cP})$.

2. The enzymatic modified starch gave the best value for brightness, roughness, oil penetration, picking strength, water absorptivity, and $\mathrm{pH}$.

3. The same results of industrial laboratory trial using enzymatic modified starch were identified for brightness, picking strength, and water absorptivity.

\section{REFFERENSES}

1. Casey, J.P.;1990, Pulp and Paper Chemistry and Chemicals Technology, Vol.3, $3^{\text {rd }}$ ed.,A wiley Interscience Publication, New York.

2. Ercg, I.J., 1984, Starch in Paper Industry, Vol. 34, no. 4, APPITA, North Sidney.

3. Glittenberg D, Becker A 1998., Cationik starches forsurface sizing. Pap Technol 39;37 - 41.

4. Holik, H., 2006, Handbook of Paper and Board, Wiley-VCH Verlag GmbH \& Co, Weinheim.

5. Laleg, M. and I.I Pikulik, 1993, Modified Starch for Increasing Paper Strength, JPPS. 19:6:J248.

6. Lehtinen, E. 2000., Pigment coating and Surface Sizing of Paper, Papermaking Science and Technology, Finnish Paper Engineers Association and TAPPI, Fapet Oy, Findland.

7. Lipponen J, Gron J, Bruun SE and Laine T ., 2004., Surface Sizingwith starch solution at high solid contents for to $18 \%$. J Pulp and paperSci. 30(3):82.

8. Maurer HW., 2001a., Surface Sizing of paper. In:Maurer HW (ed) Starch and starch products in surface sizing and paper coating. Tappi Press. GA. USA. P 83.

9. Maurer HW., 2001b., Enzyme conversion of starch for paper sizing andcoating. In: Maurer HW (ed) Starch and starch products in surface sizing andpaper coating, Tappi Press, GA, USA, P 65.

10. Schwalbe, H.C. and E.P. Gillan; 1957, Enzyme Conversion of Starch ang Starch Product in Paper Coating, TAPPI Monografph Series, no. 17.

11. Mueller, K., 2005. The Future Role of Mineral Additives in improve Company Margins - Pulp \& Paper Chemicals Outlook. New Orleans, LA.

12. Smook, G A., 2002, Handbook for pulp and paper technologist. $3^{\text {rd }}$ edition, Angus wilde publication. Vancouver. Canada.

13. Werner Kogler, 2006. Coating of Paper and Board. Handbook of Paper and Board, Wiley-VCH Verlag $\mathrm{GmbH} \& \mathrm{Co}$, Weinheim.

14. Y V Sood, Sanjay T., Renu T., P C Pande \& Rajnish T., Effect of Base Paper Characteristics on Coated Paper Quality, Indian Journal of Chemical Technology, Vol. 17, July 2010, pp. 309 - 316. 
Table 1. Coating color composition

\begin{tabular}{|c|c|c|c|}
\hline Ingredient & \multicolumn{3}{|c|}{ Variation } \\
\cline { 2 - 4 } (part/100 part of pigment) & I (\%) & II (\%) & III (\%) \\
\hline CaCO $_{3}$ & 60 & 60 & 60 \\
Clay & 40 & 40 & 40 \\
Latex & 8 & 8 & 8 \\
PVA & 5 & 5 & 5 \\
Native starch & 8 & - & - \\
Enzymatic modified starch & - & 8 & - \\
Commercial modified starch & - & - & 8 \\
Dispersant & 0.4 & 0.4 & 0.4 \\
Antifoam & 0.01 & 0.01 & 0.01 \\
Biocide & 0.01 & 0.01 & 0.01 \\
Insolubilizer & 0.01 & 0.01 & 0.01 \\
Lubricant & 0.01 & 0.01 & 0.01 \\
\hline
\end{tabular}

Table 2. The test results of coated paper

\begin{tabular}{|l|c|c|c|c|c|}
\hline \multicolumn{1}{|c|}{ Parameter } & Unit & Blank & $\begin{array}{c}\text { Native } \\
\text { Starch } \\
\text { (Variation } \\
1)\end{array}$ & $\begin{array}{c}\text { Enzymatic Modified } \\
\text { Starch (Variation 2) }\end{array}$ & $\begin{array}{c}\text { Commercial } \\
\text { Imported Starch } \\
\text { (Variation 3) }\end{array}$ \\
\hline Brightness & $\%$ & 76.0 & 79.0 & 81.0 & 79.0 \\
\hline Roughness & $\mathrm{mL} / \mathrm{menit}$ & 800 & 700 & 600 & 700 \\
\hline Oil Penetration & $1000 / \mathrm{mm}$ & 40 & 26 & 432 & 357 \\
\hline $\begin{array}{l}\text { Picking Strength } \\
\text { (IGT) }\end{array}$ & $\mathrm{P} . \mathrm{m} / \mathrm{s}$ & 164 & 335 & 78 & 90 \\
\hline Cobb & $\mathrm{g} / \mathrm{m}_{60}^{2}$ & 138 & 113 & 7.0 & 6.9 \\
\hline $\mathrm{pH}$ & & 6.8 & 6.9 & & 25 \\
\hline
\end{tabular}

Table 3. The test results of industrial laboratory trial

\begin{tabular}{|l|c|c|c|c|}
\hline Parameter & Unit & $\begin{array}{c}\text { Native } \\
\text { Starch }\end{array}$ & $\begin{array}{c}\text { Enzymatic Modified } \\
\text { Starch }\end{array}$ & $\begin{array}{c}\text { Commercial Imported } \\
\text { Starch }\end{array}$ \\
\hline Brightness & $\%$ & 80.0 & 81.0 & 80.81 \\
\hline $\begin{array}{l}\text { Picking } \\
\text { strength }\end{array}$ & P.m/s & 404.2 & 493.5 & 451.2 \\
\hline $\begin{array}{l}\text { Water } \\
\text { absorptivity }\end{array}$ & $\mathrm{g} / \mathrm{m}^{2}$ & 22.3 & 20.8 & 21.7 \\
\hline
\end{tabular}




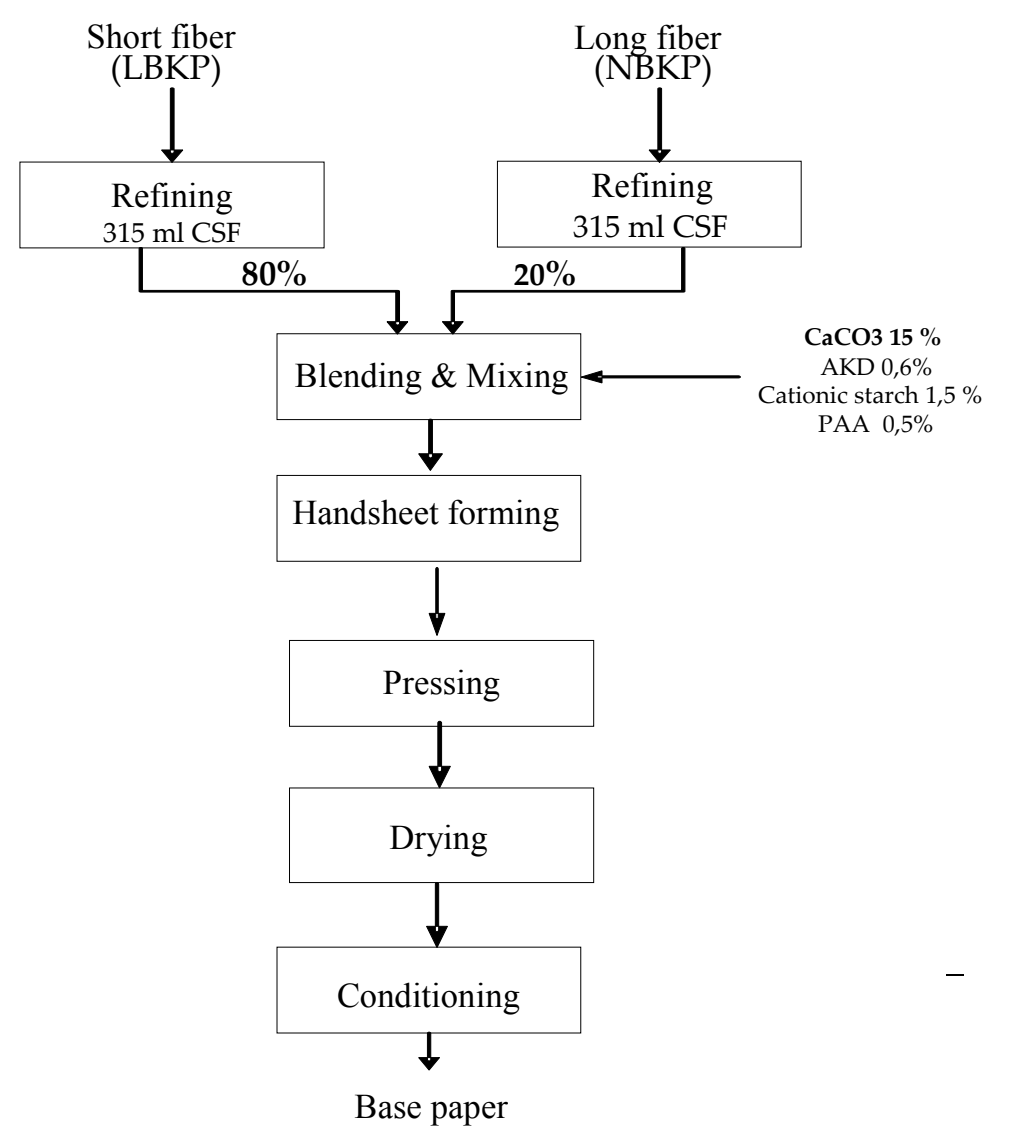

Figure 1. Diagram of base papermaking process

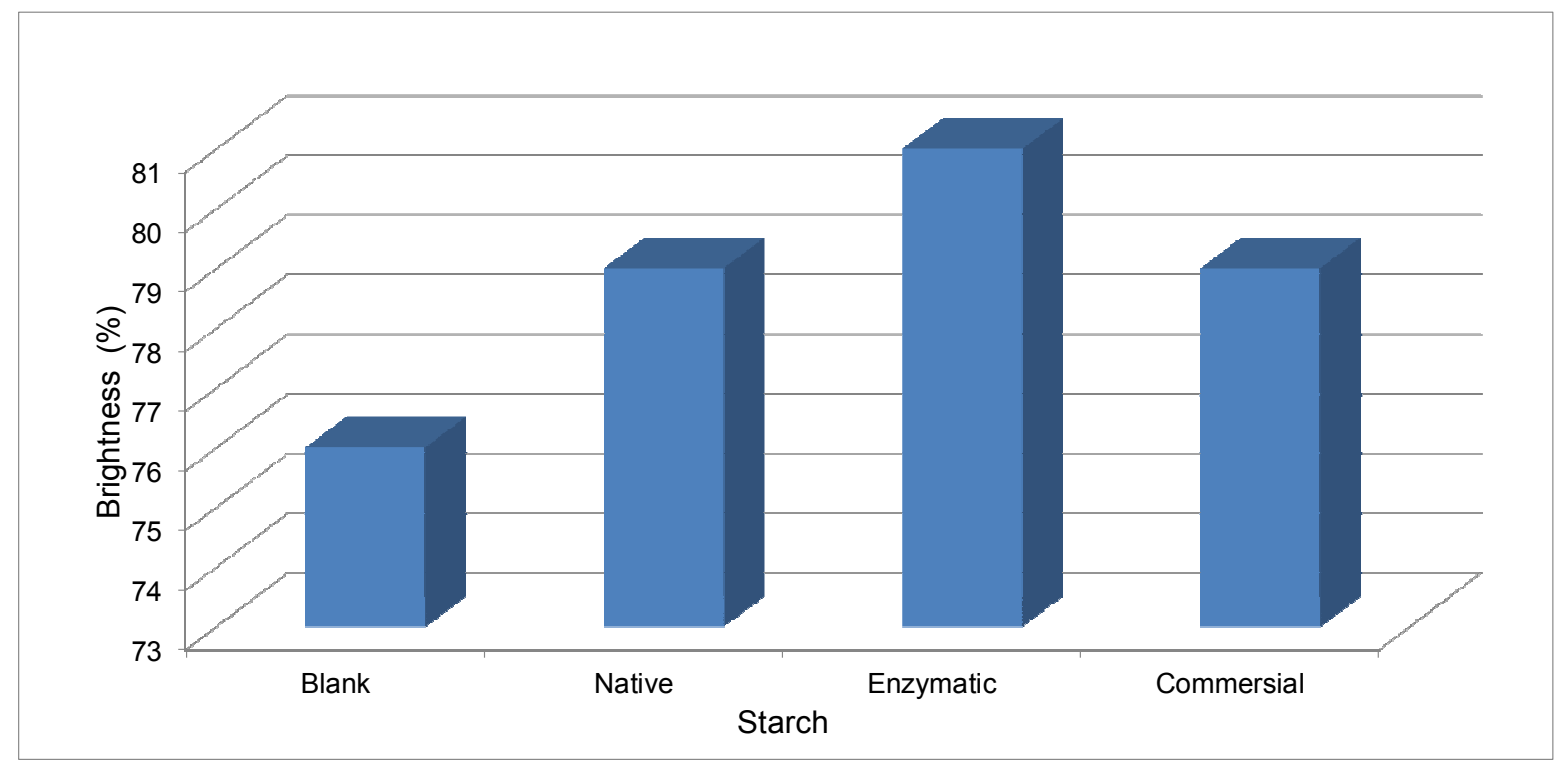

Figure 1. The influence of starch variation on the brightness of coated paper 


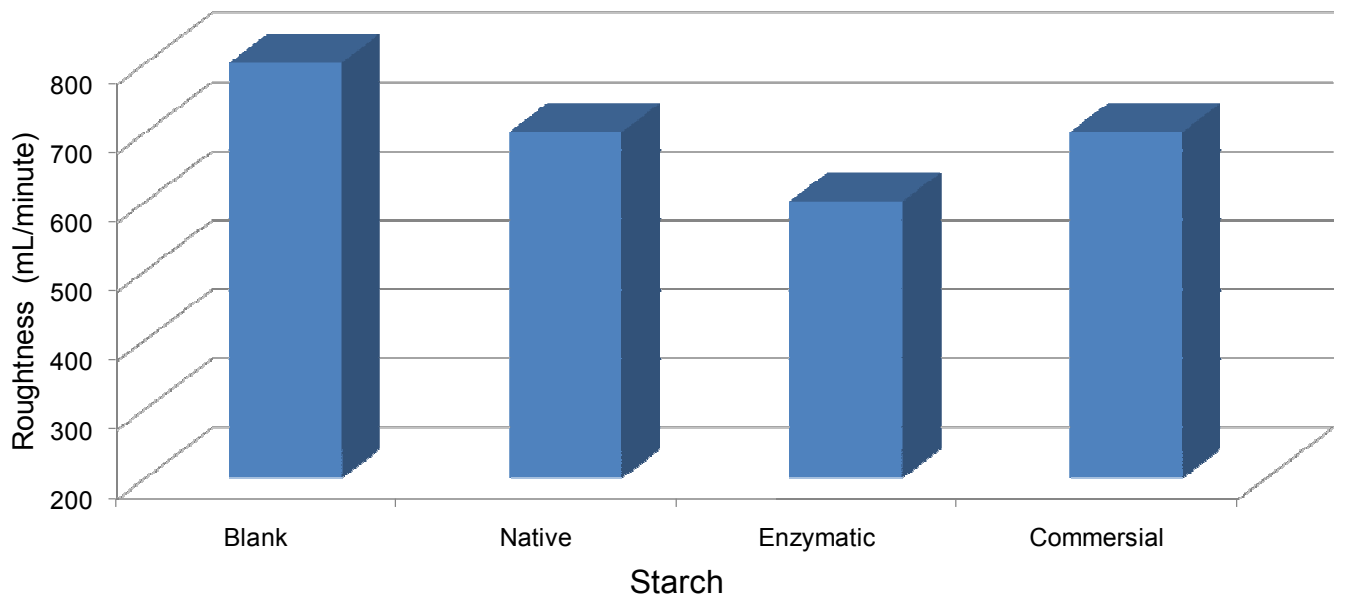

Figure 2. The influence of starch variation on the roughness of coated paper



Figure 3. The influence of starch to the oil penetration of coated paper

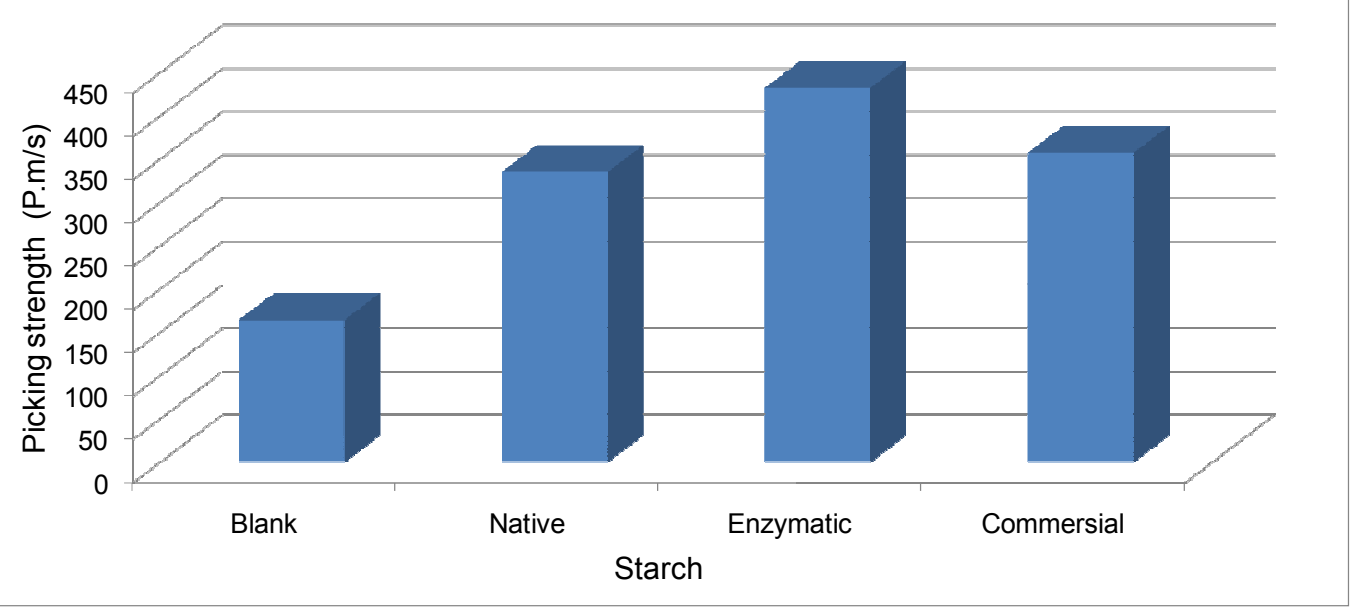

Figure 4. The influence of starch on picking strength of coated paper 


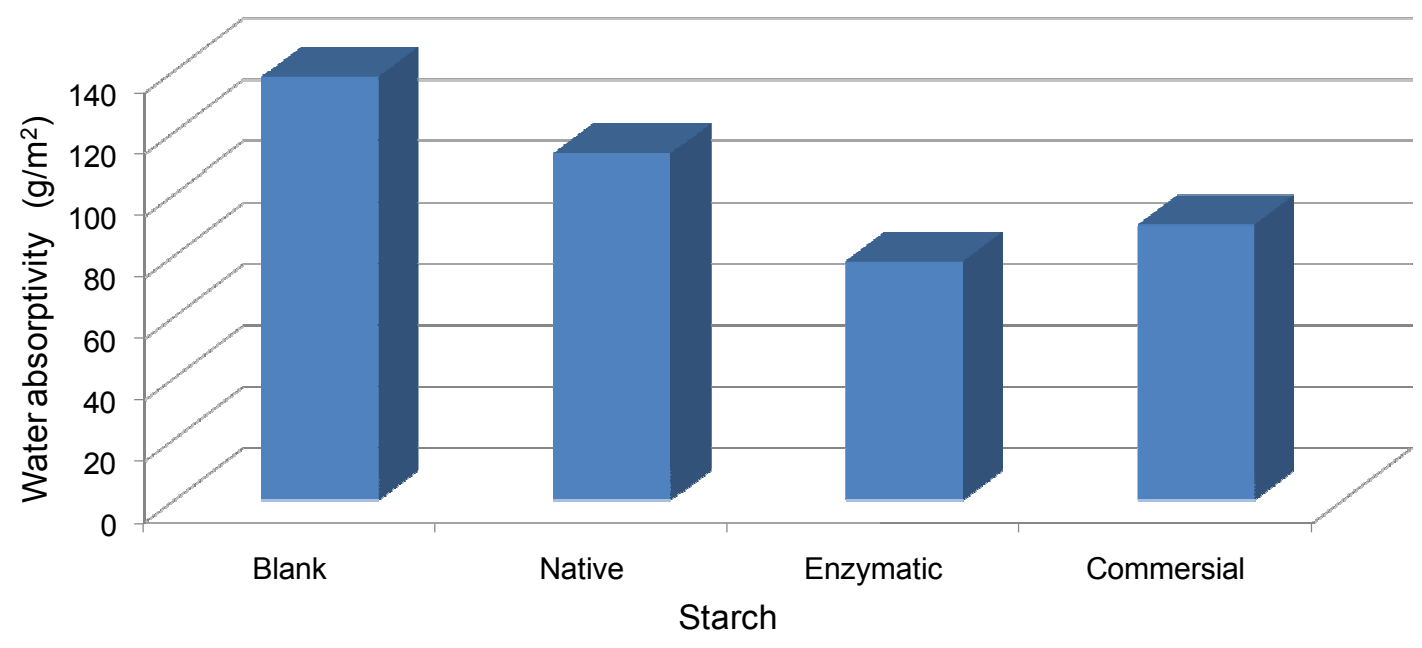

Figure 5. The influence of starch to the water absorptivity of coated paper

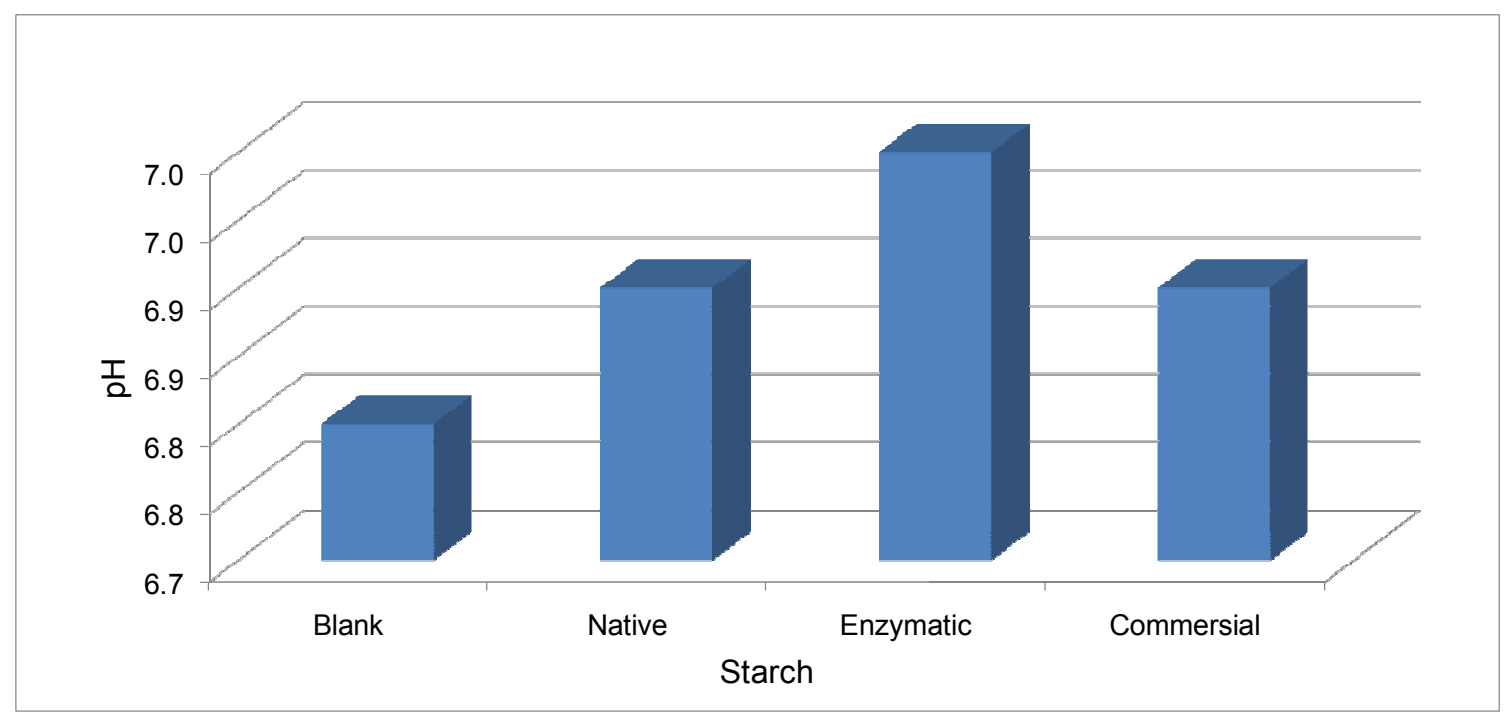

Figure 6. The influence of starch to the $\mathrm{pH}$ of coated paper 